\title{
Social assessment of technology and humanitarization of engineering in the information society*
}

\author{
V.A. Tsvyk ${ }^{1}$, I.V. Tsvyk ${ }^{1,2}$ \\ ${ }^{1}$ RUDN University \\ Miklukho-Maklaya St., 6, Moscow, 117198, Russia \\ ${ }^{2}$ Moscow Aviation Institute \\ Volokolamskoe Shosse, 4, Moscow, 125993, Russia \\ (e-mail: tsvyk-va@rudn.ru; tsvykirina@mail.ru)
}

\begin{abstract}
The article considers definitions of the contemporary technology and its social and moral assessment. In the information society, humanitarization of engineering and technical education in general becomes extremely important together with the social-humanitarian knowledge in the interdisciplinary assessment of the scientific-technological development. Technology Assessment (TA) is a new scientific discipline, a theory of assessing and forecasting the development of technology, and a practice of consulting. Based on the TA, algorithms are developed to identify negative effects of technology and to make scientifically sound decisions. An interdisciplinary dialogue on the social assessment of technology should focus not only on technocratic tasks but also on the social-humanitarian methodological and epistemological foundations of the TA. In recent years, this component of the social assessment of technology has influenced the Western-European academic discourse on Responsible Research and Innovation, which reflects the scientific understanding of the importance of ethical reflection of technical activity. Thus, there is an obvious need for the combination of the socialhumanitarian expertise of innovative technological projects with technical, mathematical and applied methods in the information age. Contemporary radical changes determined by the scientific-technological revolution require new approaches, methods and forms of interaction between people and communities, while their global nature determines universal ethical principles of these relationships. The post-modern information development of Russia will be accompanied not only by implementation of information technologies in all spheres of life, but also by the social-moral assessment of technology, humanization and humanitarization of engineering, strengthening personal professionalism and creative abilities.
\end{abstract}

Key words: technology; technosphere; technogenic civilization; information society; Technology Assessment; Responsible Research and Innovation; engineering; engineering ethics; humanitarization of engineering education

The fast progress of industrial civilization, especially in the second half of the $20^{\text {th }}$ century, has contradictory nature: it provides increasingly more means for satisfying people's growing needs for comfort and safety and determines undesirable consequences of large scale. Technology makes people's lives safer, but technicalization increases people's dependence on technology, makes the man an object of technical transformation. Humanity is increasingly turning into an "accomplice" of evolutionary processes in nature, which raises the question of responsibility for the scientific-technological progress.

* (C) V.A. Tsvyk, I.V. Tsvyk, 2020.

The article was submitted on 31.04.2020. The article was accepted on 10.06.2020. 
The transition of a number of the developed countries to the post-industrial stage in the early $21^{\text {st }}$ century did not change the situation. The contradictory nature of the scientific-technological progress determined special social, moral and ethical requirements to scientists and engineers considering the optimal (taking into account many aspects of human life) implementation of the scientific-technological achievements [27. P. 54] and the level of professional competence of specialists, especially in the field of technology. This is primarily due to the multiplication of the human impact on the world, when a professional mistake can lead to the selfdestruction of mankind or a part of it, for instance, as a result of an "unauthorized" nuclear conflict or a man-made disaster caused by a man's mistake leading to a failure of the extremely complex technical system.

Recently, social-ethical aspects have become extremely important due to the increasing social responsibility of the scientist, engineer and designer in the contemporary society. The main goal of technology is to serve people, but without harming other people and nature. Technology can no longer be considered as valueneutral and must meet not only the technical-functional requirements but also be profitable, improve living standards, safety, healthcare, the quality of natural and social environment, etc. Thus, the issue of the social assessment of technology and the general humanitarization of engineering education and activity became a focus of discussions, especially as a theoretical question with practical meaning, which is the conditions for the social assessment of technology in the information society.

\section{Technology: technogenic civilization and technosphere}

The concept of 'technology' is one of the oldest and most widespread. Until recently, it was used to define some activity or a combination of material forms. The content of the word 'technology' has historically transformed reflecting the development of production and tools of labor. The original meaning of the word is art, mastery, i.e. the activity itself and its quality. Then the concept of technology reflected a certain method of manufacturing or processing, when individual crafts were replaced by combinations of techniques and methods passed from generation to generation. Finally, the technology became a definition of manufactured material objects under the machine production - devices for production and its products [28. P. 227]. Today, there are many definitions of technology: craft, art; a set of techniques and rules for their application; activities for satisfying human needs, which lead to changes in the material world; a system of tools and machines; all material conditions necessary for the production; a system of actions for implementing an extra-natural program; a set of the produced material objects; all material means of human life; a system of artificial means of human activity; a collection of mechanical robots for work and production.

In the Philosophical Encyclopedic Dictionary, 'technology' has two meanings: (1) "all means created to implement production processes and satisfy nonproduction needs of society"; "complete or partial replacement of human 
production functions in order to facilitate labor and increase its productivity"; (2) "a set of techniques and rules for implementing something" [5. P. 123]. There are various interpretations if technology in different historical periods, but primarily as definitions of "the concept with new shades of meanings that often depend on the theoretical approach or ideological orientation of the whole context in which the concept of technology plays a role" [31. P. 86].

The definitions of technology can be combined into three groups: technology as an artificial material system; technology as a means of activity; technology as certain ways of working. The first meaning identifies one aspect of technology, but not all artificial material forms are technology (for example, products of breeding activity); therefore, the essence of technology is not limited to such definitions for they do not distinguish technology from other artificial material forms. The second definition is also insufficient for technology is interpreted as a tool of labor, a means of production, etc., but tools/means of labor are a broader concept. The third definition interprets technology as 'technological process', which, in turn, is an element of technology.

Thus, there are many definitions of technology due to its complex and multifaceted nature. All definitions of technology are useful for they reflect either the level of the scientific-theoretical knowledge of the era, certain material, scientific or social connections of technology, or its cultural context. However, no attempt to define technology can comprehensively reflect its nature due to the relative inexhaustibility of the human mind to use new cognitive means to identify new sides, connections, capabilities and limitations of the technology as the oldest type of human activity that has always been a basis for myth-making. Mythologization of technology has a long history starting from the myth of Prometheus who taught people technical skills, Daedalus and Icarus, who solved the technical task of flying with wings, to contemporary myths about anthropogenic and technocratic civilization, the seizure of power by machines.

The scientific-technological progress has led to significant changes in the nature of activities of designers who create new equipment and technology, production organizers who develop new production processes, economists who solve tasks of raising the technological level in the economic perspective. Contemporary societies are technogenic - based on the dynamics of the scientific-technological progress associated with the growth of scientific knowledge. Technogenic civilization is a special type of social development with the following features: a high rate of social change; intensive historical development; radical restructuring of the foundations of human activity; priority of innovative thinking [14. P. 97].

When the technogenic civilization reached its relatively maturity, the pace of social changes began to increase at a tremendous speed. The extensive development of history is replaced by intensive, spatial existence - by temporary. The growth reserves are no longer cultural — we witness the restructuring of the very foundations of the former ways of life and the formation of fundamentally new 
opportunities. The most important and truly epochal global change is the transition from the traditional society to the anthropogenic civilization with a new system of values based on innovations [24]. This civilization emerged in Europe, spread throughout the world and formed a new environment — the technosphere — due to the expansion of science and technology into all types of human activity and to the desire for 'technicalization' of all spheres of society. The technosphere has a complex structure, the main components of which are technical facts, knowledge and activity. Technical facts are housing and transportation, tools and objects of labor, irrigation facilities, clothes and furniture, books and decorations, etc. everything we cannot do without. Moreover, today a significant part of social resources is spent to make these objects of material culture, i.e. engineers occupy an expanding niche in the emerging social-technical reality and play an increasing role in the contemporary society [6. P. 45].

However, technical innovations are ambivalent: on the one hand, the development of engineering and technology allows to solve many problems, ensures the social welfare and serves as a basis of the technogenic civilization; on the other hand, the technological progress leads to an increase in negative consequences that can neither be predicted nor controlled. There are three main aspects in the ambivalence of technology: the subjective aspect - intentions of the subject of technical activity, human mistakes and miscalculations, i.e. anthropological features; the social aspect - the quality of society, its socialeconomic, political characteristics, confessional, ideological and other contradictions [25. P. 258]; the technical aspect - the level of the technological development and the degree of its relative autonomy.

The contemporary technology has many different features that should be identified on the interdisciplinary basis; therefore, it is necessary to consider epistemological, ontological, social, communicative and moral aspects of the technology research, in particular the social-moral assessment of technology and humanization of its creation and application.

\section{Social and moral assessment of technology}

In the information society, issues of humanitarization of engineering and technical education in general come to the fore together with the role of the socialhumanitarian knowledge in the interdisciplinary assessment of the scientifictechnological development. Scenarios for the development of the anthropogenic civilization and technological future are discussed in science, politics, and society. However, the issue of resources for the development of technology is not on the agenda, while the question is how to control the fast-developing technology. These issues in the Western-European research are defined as the Technology Assessment (TA). Already in the 19960s, this term was used in the English-language literature on the parliamentary consultations on the science and technology policy (a German analogue is Technikfolgenabschätzung — "assessment of the effects of technology"). 
TA is a new scientific discipline, a theory of assessing and forecasting the development of specific technological cases, and a practice of political consulting. The social aspect of technology plays a key role in the philosophical and interdisciplinary research, and TA allows to develop a kind of algorithms for identifying negative effects of technology and making scientifically sound decisions in the field of the scientific-technological policy in the natural, technical and humanitarian perspective.

In the Western European humanities, there is still no comprehensive analysis of the development of the social assessment of technology - there are either global TA models [9] or its various forms and practices, for example, participatory, real-time, constructive or parliamentary TA [11]. E.V. Seredkin distinguishes two stages in the development of the social assessment of technology: interdisciplinary (since the 1960s) - when it was political consulting at the US Congress, i.e. practical, technocratic; and transdisciplinary (from 2002-2003) — with a new architectonics of participation due to the new social challenges, mainly on the basis of the WesternEuropean program 'Responsible Research and Innovation' (RRI) [22. P. 67]. Recently, the concept of RRI has become a focus of serious debates due to the development of roadmaps for innovation clusters. This concept implies ethical reflection related not only to social but also to moral assessments of technology [21. P. 122].

It should be noted that before the 1960s' emergence of the concept 'social assessment of technology', there were serious works on the role of technology in the life of man and mankind [7] due to the opening of new secrets of nature, new ways of influencing it, humanization of the scientific-technical activity and increasing role of its ethical criteria. The scientific-technical activity is to serve the good of man; therefore, it is moral and humane in nature; however, the ethical principles of the scientific-technical activity are determined by the foundations of humanism. For the contemporary and future global scientific community, the further humanization of science and technology, combination of research and value approaches, and development of their ethical foundations is of particular importance [29. P. 146].

Discussions about the values for technology are often confusing mainly due to the fact that the choice of a technical system inevitably imposes certain conditions on human relations. Moreover, there is also the question of how the development of technology can ensure a positive moral assessment, but there are always contradictions between the due and the existing. In the late $19^{\text {th }}$ century, one of the founders of philosophy of technology E. Kapp defined technology as a means of cultural, moral and intellectual improvement and salvation of mankind [15]. It was the time of the indisputable and unconditional belief that the scientifictechnological progress promotes the moral progress, that science and technology free man from hard physical work and create conditions for both intellectual and moral improvement. In the $20^{\text {th }}$ century, there was some disappointment in the idea of the scientific-technological progress as contributing to the moral development. 
However, D. Johnson believed that technology is undoubtedly value-rich invention and creation of technology, the scientific-technological progress aim at improving the quality of human life, and if its design or application is spoiled in practice, the responsibility is on the one who invented or applied.

The ideas of Russian philosophers on the moral value of technology were sometimes contradictory. Thus, N.A. Berdyaev emphasized the negative role of technology for human morality for the dominance of technology and technical civilization lead to simplification of the spiritual life, to the dominance of material, utilitarian, selfish attitudes, to the lack of spirituality, to the loss of meaningful attitudes and higher values [2. P. 301]. N.F. Fedorov considered technology as playing a large role in the transformation of society according to moral ideals: he believed that "a virtue is in combining morality with knowledge and art" (technology is art); therefore, it is necessary to consider technology from the point of view of good or evil depending on its goals. He refutes the widespread notion that technology in its modern form (late $19^{\text {th }}$ - early $20^{\text {th }}$ centuries) allows the man to dominate nature: the negative moral value of technology is that it satisfies empty whims, depletes natural resources, increases social discord, and military technology serves the self-destruction of mankind.

Thus, social relations negatively assessed from the moral point of view can and should be replaced by morally positive relations in the course of the technological development. Science and technology that serve the 'common cause' would unite the humanity: "The obstacle for creating a moral society is that nothing can absorb the resources of people which are currently spent on hostility; in the whole world history, there is no event that would threaten by the death of society and, thus, would join all forces and cease all strife, all hostility" [3. P. 424]. According to Fedorov, the regulation of nature as a common cause of mankind is invariably carried out with the latest technical achievements; thus, the moral significance of technology is determined by the moral character of the highest goal - to fight death. In understanding the moral aspects of technology, Russian philosophers provide the ethical assessment of both the use of technology and its consequences to solve the task of the fair distribution of the benefits and negative consequences of technology by the moral justification of human efforts and use of natural resources for the development of technology.

Today the interdisciplinary dialogue about the need for the social assessment of technology involves technocratic elites, representatives of social and humanitarian knowledge, which allowed to develop methodological and epistemological foundations of the TA [19]. The social assessment of technology implies three different levels: 1) the social-ecological and social-economic assessment of possible consequences of the new technology, which aims at providing political advice on state support for certain projects; 2) the state expertise and environmental assessment at the regional level; 3) the environmental management and audit of the certain enterprise [30. P. 72]. However, the social 
assessment of technology should be considered more broadly, including its social and ethical effects [12]. European scientists have repeatedly noted that today the focus should be not so much on technology as on its relationship with society and 'creation of technical artifacts'. According to A. Grunwald, the technical is a social construct, and the distinction 'technical-non-technical' is not ontological but pragmatic - the result of reflection on the invariance of actions [9. P. 12]. Thus, the technological development does not follow the natural evolution for it is a planned target process. Science is an organic part of social practice. Based on the social assessment of technology, a kind of 'recognition and action algorithms' are developed to make scientifically sound decisions in the scientific-technical policy in the natural, technical and social-humanitarian perspective [21. P. 123]. When the influence of engineering becomes global, its decisions are already beyond the narrow professional scope. Although the technical elite continues to be responsible for the scientific-technological development, the final decision become public for no economic or technical feasibility can justify environmental, moral, psychological damage.

The ethical component of the social assessment of technology is presented in the concept "Responsible Research and Innovation" (RRI) recently introduced in the Western-European academic discourse. The very term 'responsible' points to the need for ethical reflection of technical activity. A. Grunwald identifies three levels of responsibility in innovative projects that determine the scientifictechnological vector of the contemporary social development and constitute the human world: morality, epistemology and management [9]. Thus, the responsible development of technology is a balance between its increasing positive contribution and decreasing negative consequences, which implies a study of application (maximum satisfaction of the needs of man and society) and the moral assessment of potential consequences (negative or unexpected) of the application of technology [17. P. 754].

The moral assessment of technology does not mean its critique and hyperbolization of its negative consequences. The calls to return 'back to nature' are more than naive regarding the current level of development. It is unlikely that the man who uses a huge number of technical devices all the time in professional activities and in everyday life would abandon advantages of the contemporary technology. This is also impossible because technology is an essential part of our lives with a decisive impact on social processes including the development of the man (for instance, education or communication).

Does the fight against technocracy mean a denial of the technological development? Actually, today the technical community based on the division of labor more than ever needs relationships of trust and dignity in its supra-individual system, to which every specialist contributes and from which everyone benefits. The man has always used technology, but the question of its meaning is relatively new for we have just realizes that the fast technological development has limitations 
and costs. The growth of consumption is limited by the supply of raw materials, which was convincingly and irrefutably argued by the Club of Rome. According to H. Sachsse, there are also spiritual limits: "The rejection of technology and its condemnation are everywhere: love to nature and simple life; need for a clear understanding of the situation; economic estimates of stockpiles and waste management; a sense of justice, which protests against some groups living much better than others, and the desire for changes in the system, which would lead to a fundamental revolutionary transformation of the social structure - all this effects our attitudes to technology" [4. P. 436].

The negative attitude to technology and the desire to put limits for its development has nothing to do with its social and ethical assessment: the moral dimension of technology is a result of the civilizational development, and the personal dimension of technology is the most important means of self-development and self-realization and a tool for mastering cash. The anthropological understanding of technology was provided by T. Adorno: "Whether modern technology brings benefit or harm depends not on technicians or technology itself, but on how it is used by society" [4. P. 381].

In the social assessment of technology, two extremes should be avoided. First, we should not absolutize the power of the purely technical approach to human wellbeing: certainly, technology contributes significantly to an increase in such wellbeing, but technological achievements should be considered within the social development. Second, we should avoid absolutization of the social factor in assessing science and technology: no society can eliminate contradictions determined by negative consequences of the scientific-technological progress. Competent social-political decisions can minimize such consequences, so responsibility for technology can be expanded from individual ethics to the socialpolitical sphere.

Thus, the internal relationship between various aspects of technology and other areas of knowledge and practical activity can be examined comprehensively only on the basis of the social assessment with the moral assessment being its integral part. The necessity of the moral assessment of technology is due to unprecedented acceleration of the scientific-technological progress in the information society, which raised the question of the relationship between goals and means of technical activities, humanization of engineering, and moral responsibility of the scientist, engineer and designer who create and use technical systems.

\section{Features of engineering in the contemporary society}

Questions of social and other consequences of technology and ethical aspects of engineering were raised at the very moment this profession appeared. Today the ignorance of consequences of introducing new equipment and technology can lead to irreversible negative effects for the humankind and nature; therefore, it is necessary to rethink the very idea of the scientific-technical and social-economic 
progress. When the impact of engineering activity becomes global, its decisions cease to be a professional task and become the focus of general discussion, i.e. decisions on technological projects are the prerogative of society. No economic, technical or even state significance can justify their social, moral, psychological or environmental damage. Open discussions on advantages and disadvantages in the media, social expertise, estimates of alternative projects and plans are the most important attribute of today's life, a condition and consequence of its democratization [8. P. 137].

Significant changes in the structure of engineering activity and social mechanisms of its functioning, at least partially, allowed society to control consequences of technical projects in the foreseeable future for the social assessment of technology becomes an integral part of engineering in the information society. Today there is an urgent need for rethinking the relationship between engineering and its products due to the increasing complexity of artificial objects, differentiation of labor, alienation of products from their production, and a new understanding of the ethical component of engineering.

The engineer is a specialist with a higher technical education. Engineering professions are among the most mass professions of highly skilled labor. Engineers work in various fields: factories, construction sites, mines, army, aviation, transportation, research institutes. Initially, engineers were people who control military vehicles. First civil engineers in the $16^{\text {th }}$ century built bridges and roads; first educational institutions for engineers appeared a century later. Today the system of training and professional activity of engineers includes a wide range of specialties: for instance, there are 167 engineering professions in the All-Russian Classifier of Occupations of Workers, Positions of Employees and Tariff Ranks.

The engineering professional community, like any other, has special norms and values that are developed by both the social-professional group and the wider social context. These norms and values form a hierarchy depending on both the logic of the internal development of engineering and the wider cultural context. The hierarchy of professional norms and values of the engineering community is reproduced in special vocational training and corporate self-identification. In Russia, the profession of engineer is one of the most widespread (a third of specialists with higher education): the engineer is a specialist of high culture, an expert in advanced equipment and technologies, economics and organization of production, capable of solving engineering tasks and inventing new technologies. In the contemporary world, there is a twofold tendency in engineering work: on the one hand, it becomes more intellectualized; on the other hand, its creative activities decrease.

The professional activity of the engineer combines the scientific approach with the ability to solve engineering tasks. The scientific approach implies knowledge in certain fields of science and of results of theoretical and experimental studies of physical, social and economic processes, collecting information on technical devices designed for similar functions, materials, production methods, market 
conditions, needs of society. In some cases, the main goal is to develop theory, principles and methods of the research; in other cases - to create new technology or develop new production processes based on the scientific knowledge and generalization of engineering practice. Nevertheless, scientific and engineering issues are closely related: the scientific research results provide the engineer with the scientific-methodological basis to make optimal decisions when designing systems and processes; while designing new technology allows us to identify the most promising areas of the research.

Depending on forms of labor and professional requirements, there are different groups of engineering professions: designers of instruments or equipment; technologists involved in processing; economists analyzing and planning economic results; organizers of labor. However, they all should have a sense of responsibility for the rational use of labor and technology depends on its efficient organization, which needs creativity and independence in addition to technical thinking and knowledge.

\section{Ethical regulation of engineering}

Until the $20^{\text {th }}$ century, responsibility of scientists, inventors and engineers for negative consequences of technical innovations has not been discussed. The professional ethics of the engineer was corporate, focused on the protection of corporate interests and responsibility to the employer. The engineer was not a socalled 'free profession' for he depended on the employer economically and professionally, and, thus, was professionally responsible to him. Later, when first associations of engineers appeared, the engineer was responsible also to his colleagues [23. P. 112]. According to the engineers' codes of ethics in the $19^{\text {th }}-$ early $20^{\text {th }}$ centuries, the member of the engineers' association was primarily obliged to protect corporate interests even inconsistent with public interests. An illustration of this is the 1932 expulsion from the American Association of Civil Engineers of B. Jacobson and J. Reina on charges of violating the professional ethics. They were accused of critical press statement exposing the technical miscalculations and lowquality work at the dam construction near Los Angeles. However, despite the fact that their criticism was recognized as fair and helped to prevent a possible catastrophe (the dam could have suddenly collapsed), i.e. to achieve the public good, it was classified as an act deserving the professional-ethical condemnation. One of the most important norms in the Code of the American Association of Civil Engineers forbade any member to publicly criticize their colleagues without their knowledge and prior consent. Violation of this norm served as a formal reason for the expulsion [16. P. 76].

This situation began to change only after the World War II. When the destructive power of the scientific-technological progress became obvious, professional associations of engineers and other technical workers could no longer ignore public interests as the most important guideline for professional activity. 
Therefore, since the last quarter of the $20^{\text {th }}$ century, the charters of engineering communities began to declare the public safety and good a value that determines the general 'vector' of the professional behavior. For instance, in its Charter of 1984, the Association of American Engineering Unions demanded that their members had to be competent and law-abiding specialists, honestly fulfilling their obligations, and at the same time had to take care of public welfare and ensure the safety of people.

However, these requirements are often declarative, and some countries still practice dismissing those engineers (technicians) who are ethically responsible to society and warn it of possible negative consequences of certain technical projects and solutions. The free market mechanisms often hinder any possibility for the technical worker to be responsible to society and humankind. Therefore, the lack of an effective and universally recognized professional ethical code of the engineer/technician has an objective basis [1]. The resumption of interest to the engineers' responsibility in the second half of the $20^{\text {th }}$ century was also determined by the terrifying results of the military technology and negative consequences of the anthropogenic impact on nature. Thus, to be responsible means for the engineer to understand and explain the consequences of one's actions to oneself and other people (future generations).

There are various professional ethical codes that act as external regulators of engineering activity in the contemporary society. Their main requirement is that the engineer should fulfill his professional duties, give priority to the safety, health and well-being of people. The efficiency of these codes (and similar in bioethics, scientific ethics, etc.) is questioned due to their abstract wording. One of their essential requirements is the need to include the understanding of the responsibility for foreseeing and assessing consequences of technical actions, which can be attributed both to the individual moral responsibility of the engineer and to the tasks of engineering associations/commissions on ethics. Anyway, the engineer's moral responsibility for assessing possible consequences of their activities is necessary but not sufficient prerequisite for the satisfactory solution of the responsibility task in technology.

Today the engineer should listen not only to scientists and technical experts but also to his conscience and public opinion. When making a technical decision, he is morally responsibility for it, especially for its negative consequences, which sometimes implies direct or legal responsibility. The engineer's moral sense of duty is important for following ethical principles in technical activity, but social mechanisms that ensure moral regulations and ethical standards are even more important. Such mechanisms can work only if there is a developed civil society with an engineering community, i.e. developed public opinion and independent nongovernmental organizations which ensure that moral principles are put into practice. All engineers should value the opinion and recommendations of one's professional community, which is possible if professional and corporate interests do not 
contradict public interests. In this case, the engineer can act as a determined 'humanizer' of nature objects to satisfy the needs of society, based on the engineers' ethics that makes an emphasis not so much on the professional perspective as on the social aspects of the scientific-technological development.

\section{Humanitarization of engineering in the information society}

The world becomes more complex and diversified due to the increasingly important role of technology and technosphere, which makes the profession of engineer and the engineering activity cover almost all spheres of public life. The public opinion defines the engineer inconsistently - as a creator of new equipment and technology, designer, researcher, production organizer. There are concepts of genetic and social engineering, which allows to claim the 'manufacturability' of a wide range of systems - from traditional technical to biological and social. Therefore, today engineering activities include not only traditional technological calculations and design of complex social-technical systems but also expertise in managerial and political decisions [6].

The growing role of technology in society, new scientific discoveries, blurring borders between countries, academic mobility, changing gender stereotypes and government policies determine the need for changes in the engineering education for the engineer has to solve fundamentally new technical and economic tasks. The engineer professionalism requires not only professional knowledge and skills but also civil maturity, psychological stability, a sense of patriotism and moral reliability [26]. The engineer should follow both the scientific-professional principles and internal and external moral and psychological principles of selfcontrol. Today the life is so dynamic, and science, technology and social life are so interconnected that any technical solution inevitably entail consequences that affect the life, health and safety of people. Therefore, the professional responsibility of the engineer steadily increases and demands that ethical principles in the field of technical activity and a sense of duty should be taught to the future engineers already at the stage of professional training.

Humanization of engineering education is closely related to humanitarization of engineering in general for the ability to socially and ethically assess one's own professional activity is developed during the professional education. Humanitarization of engineering education is an important aspect of the general humanization of knowledge and education at the current post-non-classical stage in the development of science in the information society. Humanitarization implies the scientific research turn to the man and filling educational programs of future engineers with humanitarian content [20. P. 41]. At the same time, humanitarization is a way for learning and understanding the spiritual values in general, not only in profession.

In 1992, the World Congress on Engineering Education made a list of requirements for the graduate of engineering universities: professional competence 
(the unity of theoretical knowledge and practical skills, willingness to carry out various types of professional activities within the educational standard); communication competence (ability to communicate within one's professional duties - good command of written and oral speech; ability to read professional literature and discuss professional problems in at least one foreign language; ability to make and understand technical documents, to work on a computer as a confident user with programming skills; knowledge of ethics and psychology of business and personal communication, ability to organize work of a group); ability to be creative in solving professional tasks, non-standard tasks, and willingness to develop and implement a plan of professional actions; awareness of one's responsibility; a sustainable, informed and positive attitude to the profession, focus on life-long professional and personal improvement; mastery of methods for the scientific organization of engineering labor, technical and economic analysis of production to rationalize, optimize, renovate and also to protect nature; understanding of trends in the development of science and technology; ability to conduct research [16. P. 70]. This list exceeds purely professional competencies, which indicates that the efficiency of scientific, technical and innovative activities should take into account social, ethical and environmental aspects that are not always legally classified and have rather a moral nature.

Thus, today researchers, engineers and designers can no longer consider themselves ethically neutral. In the era of high technology and knowledge society, a new ethics of engineer responsibility develops: "For the full development of the engineer's personality, it is necessary that he and his professional world are considered a special area of lifestyle. However, the engineer becomes completely and happily matured only if he developed his ethical and social responsibility" [13. P. 418]. Today the world is so full of technologies that the engineering ethics cannot be limited to moral and ethical issues of engineering and should include the ethical attitude to the use of technology by society and its members. Careless attitude to complex technologies can have disastrous consequences not to mention its usage for other purposes than intended. The ethics of technology serves as an important social means to influence the scientific-technological development not for the active elimination of conflicts but for creating social conditions for their rational resolving. Under the ongoing uncovering of the secrets of nature and developing new ways to influence it, humanization of science and technology is of particular importance. Scientific and technical activities are to serve the good of man; therefore, ethical principles of science and technology (combination of the research and value approaches) should be largely determined by the humanistic interests of the contemporary and, which is even more important, future generations.

The internal relationship between various sides of technology and other areas of knowledge and practice can be understood only on the basis of the well-developed 
and methodologically verified social assessment for technology together with science plays a decisive role in the social, material and spiritual life of all peoples. For instance, the development of technology makes us reconsider some most important characteristics of science in its relation to technology, in particular, to the successes and capabilities of technology; while technology often has a decisive impact on many important economic, environmental, social, scientific and political decisions. Its social assessment ensures a responsible use of technical systems.

Thus, there is an obvious need for an integral approach combining social and humanitarian expertise of innovative technological projects in the information age. Fundamental changes of the world determined by the scientific-technological revolution demand new approaches, methods and forms of relationships between people and their communities, and the global nature of changes determines the universality of ethical principles of these relationships. The post-modern information civilization implies not only by the development and implementation of information technologies in all spheres of life, but also by the social-moral assessment of technology, humanitarization and humanization of engineering activities, and comprehensive development of the engineer's professionalism and creative abilities by both new moral and ethical factors (socially valuable ideas and individual intellectual preferences) and techno-humanitarian synthesis that would eliminate narrow technocratism.

\section{References}

[1] Al-Ani N.M. Filosofiya tekhniki: ocherki istorii i teorii [Philosophy of Technology: Essays on History and Theory]. Saint Petersburg; 2004 (In Russ.).

[2] Berdyaev N.A. Tsarstvo dukha i tsarstvo kesarya [Kingdom of Spirit and Kingdom of Caesar]. Moscow; 1995 (In Russ.).

[3] Fedorov N.F. Sochineniya [Works]. Moscow; 1982 (In Russ.).

[4] Filosofiya tekhniki v FRG [Philosophy of Technology in FRG]. Moscow; 1989 (In Russ.).

[5] Filosofsky entsiklopedichesky slovar [Philosophical Encyclopedic Dictionary]. Moscow; 2003 (In Russ.).

[6] Gavrilina E.A. Inzhenernoe tvorchestvo v informatsionnom obshchestve: tipologiya, dinamika, kriterii otsenki inzhenernoy kompetentsii [Engineering Creativity in the Information Society: Typology, Dynamics, Criteria for Assessing Competences]. Moscow; 2011 (In Russ.).

[7] Gerasimova I.A. Neustranimost neopredelennosti v sotsialnoy otsenke tekhniki [Unavoidable uncertainty in the social assessment of technology]. Epistemology \& Philosophy of Science. 2012; 2 (In Russ.).

[8] Gorokhov V.G., Deker M. Sotsialnye tekhnologii prikladnykh mezhdistsiplinarnykh issledovaniy v sfere sotsialnoy otsenki tekhniki [Social technologies of the applied interdisciplinary research in the social assessment of technology]. Epistemology \& Philosophy of Science. 2013; 1 (In Russ.).

[9] Grunwald A. Responsible innovation: Bringing together technology assessment, applied ethics, and STS research. Enterprise and Work Innovation Studies. 2011; 7.

[10] Hahn J., Ladikas M. Responsible research and innovation: Global perspective. Enterprise and Work Innovation Studies. 2014; 10. 
[11] Hahn J., Merz C., Scherz C. Identity shaping: Challenges of advising parliaments and society a brief history of parliamentary technology assessment. Philosophy of Science and Technology. $2015 ; 2$.

[12] Handbuch Technikethik. Grunwald A. (Hrsg.). Stuttgart; 2013.

[13] Hunning A. Inzhenernaya deyatelnost s tochki zreniya eticheskoy i sotsialnoy otvetstvennosti [Engineering in the ethical and social responsibility perspective]. Filosofiya tekhniki $v$ FRG. Moscow; 1989 (In Russ.).

[14] Istoriya i filosofiya nauki (Filosofiya nauki) [History and Philosophy of Science (Philosophy of Science)]. Moscow; 2019 (In Russ.).

[15] Kapp E. Grundlinien einer Philosophie der Technik; Zur Entstehungsgeschichte der Kultur aus neuen Gesichtpunkten. Duesseldorf; 1978.

[16] Nauchno-tekhnichesky progress i eticheskaya paradigma XXI veka [Scientific-Technological Progress and Ethical Paradigm of the $21^{\text {st }}$ Century]. V.A. Tsvyk (Ed.). Moscow; 2018 (In Russ.).

[17] Owen R., Macnaghten P., Stigoe J. Responsible research and innovation: From science in society to science for society, with society. Science and Public Policy. 2012; 39.

[18] Rozin V.M. Sushchnost tekhniki [The essence of technology]. Pravo, mirovozzrenie, filosofiya. 2004; 1-2 (In Russ.).

[19] Sadowski J., Guston D. Technology assessment in the USA: Distributed institutional governance. Journal for Technology Assessment in Theory and Practice. 2015; 1.

[20] Seredkina E.V., Chernikova I.V. Gumanitarizatsiya inzhenernogo obrazovaniya i sotsialnaya otsenka tekhniki [Humanitarization of engineering education and social assessment of technology]. Technologos. 2015; 2 (In Russ.).

[21] Seredkina E.V. Otvetstvennye issledovaniya i innovatsii, sotsialnaya otsenka tekhniki i ustoychivoe razvitie [Responsible research and innovation, social assessment of technology and sustainable development]. PNRPU Sociology and Economics Bulletin. 2015; 2 (In Russ.).

[22] Seredkina E.V. Sotsialnaya otsenka tekhniki v povorotnye vremena: vyzovy transdistsiplinarnosti i natsionalnogo [Social assessment of technology in the times of change: Challenges of the transdisciplinary and national]. Technologos. 2017; 2 (In Russ.).

[23] Sovremennye filosofskie problemy estestvennykh, tekhnicheskikh i sotsialno-gumanitarnykh nauk [Contemporary Philosophical Issues of Natural, Technical and Social Sciences]. V.V. Mironov (Ed.). Moscow; 2006 (In Russ.).

[24] Stepin V.S. Istoriya i filosofiya nauki [History and Philosophy of Science]. Moscow; 2011 (In Russ.).

[25] Tsvyk A.V. Etika politicheskoy otvetstvennosti v mezhdunarodnykh otnosheniyakh [Ethics of political responsibility in international relations]. RUDN Journal of International Relations. 2017; 17 (2) (In Russ.).

[26] Tsvyk V.A., Tsvyk I.V. Professional development in the information society: Challenges and prospects. RUDN Journal of Sociology. 2018; 18 (3).

[27] Tsvyk V.A., Tsvyk I.V. Moral education of the youth in the information society. Voprosy Filosofii. 2020; 4.

[28] Tsvyk I.V. Filosofiya tekhniki: sushchnost, perspektivy razvitiya. [Philosophy of technology: Essence and development prospects]. Lichnost. Kultura. Obshchestvo. 2010; 12 (1) (In Russ.).

[29] Tsvyk I.V. Nravstvennaya otsenka tekhniki [Moral assessment of technology]. RUDN Journal of Philosophy. 2014; 2 (In Russ.).

[30] Tsvyk I.V. Sotsialnaya otsenka tekhniki [Social assessment of technology]. RUDN Journal of Sociology. 2011; 5 (In Russ.).

[31] Voronin A.A. Kontury gumanitarnoy ekspertizy [Contours of the humanitarian expertise]. Chelovek. 2014; 1 (In Russ.). 


\title{
Социальная оценка техники и гуманитаризация инженерной деятельности в информационном обществе*
}

\author{
В.А. Цвык ${ }^{1}$ И.В. Цвык ${ }^{1,2}$ \\ ${ }^{1}$ Российский университет дружбы народов \\ ул. Миклухо-Маклая, 6, Москва, 117198, Россия \\ ${ }^{2}$ Московский авиационный институт \\ Волоколамское шоссе, 4, Москва, 125993, Россия \\ (e-mail: tsvyk-va@rudn.ru; tsvykirina@mail.ru)
}

\begin{abstract}
Статья посвящена определению сущности современной техники, ее социальной и нравственной оценке. Отмечается, что в условиях информационного общества на первый план выходит проблема гуманитаризации инженерного и в целом технического образования, а также роль социально-гуманитарного познания в междисциплинарной оценке научно-технологического развития. Technology Assessment (TA) - новая научная дисциплина, теория оценки и прогнозирования развития конкретных технологий, а также практика политического консультирования. На базе ТА разрабатываются алгоритмы распознавания негативных последствий техники в целях принятия научно обоснованных решений в сфере научно-технической политики. Подключение к междисциплинарному диалогу о социальной оценке техники помимо технократической элиты представителей социально-гуманитарного знания позволило разработать методологические и эпистемологические основания ТА. Этический компонент социальной оценки техники прослеживается в укоренившемся в западноевропейской академической среде концепте «Responsible Research and Innovation». Очевидна необходимость интегрального подхода, призванного объединить социально-гуманитарную экспертизу инновационных технологических проектов, технонаучную парадигму и прикладную этику в информационном обществе. Кардинальные перемены в современном мире, обусловленные научно-технологической революцией, требуют поиска новых подходов, способов и форм взаимоотношений между людьми и общностями, а глобальность перемен обусловливает планетарный характер этических принципов, лежащих в основе этих взаимоотношений. Вхождение России в постсовременную информационную цивилизацию будет сопровождаться не только освоением и внедрением во все сферы жизни информационных технологий, но и социально-нравственной оценкой техники, гуманизацией и гуманитаризацией инженерной деятельности, укреплением и развитием профессионализма личности и ее творческих способностей.

Ключевые слова: техника; техносфера; техногенная цивилизация; информационное общество; Technology Assessment; Responsible Research and Innovation; инженерная деятельность; инженерная этика; гуманитаризация инженерного образования
\end{abstract}

\footnotetext{
* (С Цвык В.А., Цвык И.В., 2020.

Статья поступила 31.04.2020 г. Статья принята к публикации 10.06.2020 г.
} 